Published in final edited form as:

Soft Matter. 2013 May 14; 9(18): 4368-4380. doi:10.1039/C3SM27705D.

\title{
Bacteria-surface interactions
}

\author{
Hannah H. Tuson ${ }^{1}$ and Douglas B. Weibel ${ }^{1,2, *}$ \\ ${ }^{1}$ Department of Biochemistry, University of Wisconsin-Madison, Madison, WI 53706 \\ ${ }^{2}$ Department of Biomedical Engineering, University of Wisconsin-Madison, Madison, WI 53706
}

\begin{abstract}
The interaction of bacteria with surfaces has important implications in a range of areas, including bioenergy, biofouling, biofilm formation, and the infection of plants and animals. Many of the interactions of bacteria with surfaces produce changes in the expression of genes that influence cell morphology and behavior, including genes essential for motility and surface attachment. Despite the attention that these phenotypes have garnered, the bacterial systems used for sensing and responding to surfaces are still not well understood. An understanding of these mechanisms will guide the development of new classes of materials that inhibit and promote cell growth, and complement studies of the physiology of bacteria in contact with surfaces. Recent studies from a range of fields in science and engineering are poised to guide future investigations in this area. This review summarizes recent studies on bacteria-surface interactions, discusses mechanisms of surface sensing and consequences of cell attachment, provides an overview of surfaces that have been used in bacterial studies, and highlights unanswered questions in this field.
\end{abstract}

\section{Introduction to microbial surface sensing}

Molecular phylogeny and geobiology suggest that microorganisms emerged $~ 3.5-3.8$ billion years ago, ${ }^{1,2}$ a mere billion years after the formation of the Earth. Since that time, microbes have done remarkably well- their total number on Earth is estimated to be $4-6 \times 10^{30}$, and they are found in nearly every terrestrial environment sampled to date. ${ }^{3} \mathrm{~A}$ central hypothesis in microbiology is that the majority of bacteria in the biosphere live in communities that are associated with surfaces, ${ }^{4}$ and that this association has played an important role in the success of bacteria in colonizing different environments. In addition to nucleating cell growth into communities, surfaces have a range of characteristics that protect cells from predation and other environmental threats and facilitate the conservation of the genotype.

Bacterial attachment to surfaces has long been a topic of study. Several of the first reports on this subject came from PS Meadows, who examined the effect of salinity on attachment of both marine and freshwater organisms to glass slides. ${ }^{5}$ Many early studies focused on attachment to biotic surfaces such as teeth ${ }^{6}$ and epithelial cells, ${ }^{7,8}$ and an interest in abiotic surfaces soon followed. ${ }^{9-14}$ The number of papers indexed by PubMed on bacterial attachment to surfaces was less than 10 per year throughout the 1970s and increased to 115 in 2011. ${ }^{15}$ Early reviews in this area, including an excellent discussion of the attachment of Staphylococcus aureus to surfaces by Katsikogianni and Missirlis, ${ }^{16}$ set the stage for many of the advances that have occurred in the past decade.

*Corresponding author information: Department of Biochemistry, 471 Biochemistry Addition, 433 Babcock Drive, Madison, WI 53706, United States, Phone: (608) 890-1342, Fax: (608) 265-0764, weibel@ biochem.wisc.edu. 


\section{Advantages of bacterial attachment to surfaces}

Adhering to surfaces provides bacteria with many advantages. Attachment to horizontal surfaces stimulates bacterial growth (particularly in nutrient-poor environments) as organic material suspended in liquid settles, is deposited on surfaces, and increases the local concentration of nutrients. ${ }^{17}$ Similarly, increasing the substrate surface area (e.g., by adding glass beads to a culture container) provides more area on which nutrients can adsorb, enabling cells to grow at nutrient concentrations that would normally be too low to support growth. ${ }^{18}$ Caulobacter crescentus is a fascinating example of a bacterium that takes advantage of surface attachment to optimize nutrient uptake. $C$. crescentus oscillates between stalked cells that adhere tightly to surfaces using a protein holdfast and motile cells that lack this organelle and instead have a polar flagellum. This phenotypic switch makes it possible for cells to adapt to both nutrient-rich (favoring motility) and nutrient-poor (favoring adhesion) environments. ${ }^{19}$

In addition to surface attachment facilitating nutrient capture, some bacteria obtain necessary metabolites and co-factors directly from the surfaces to which they adhere. Shewanella and other genera of bacteria that grow on metal surfaces can use metals such as iron and magnesium as terminal electron acceptors in respiration. ${ }^{20,21}$ Extracellular organelles facilitate the transport of ions between cells and surfaces. For example, Geobacter sulfurreducens uses pili to conduct charge transport between cells and surfaces. Shewanella oneidensis uses an outer membrane protein complex to form an electron bridge between the periplasm and the extracellular environment. ${ }^{22}$

Bacteria attached to surfaces often exist as biofilms, which play several protective roles. The extracellular polymeric substance (EPS) secreted by cells in biofilms that are attached to surfaces provides protection from mechanical damage and shear caused by fluid flow. ${ }^{23,} 24$ Additionally, biofilms often exhibit resistance to antibiotic treatment. ${ }^{4}$ Several different mechanisms contribute to this resistance, including (1) the barrier function of the biofilm matrix; (2) the presence of dormant persister cells and highly resistant small colony variants; (3) and upregulation of several biofilm-specific antibiotic resistance genes. These and other mechanisms are reviewed in detail by Mah and O'Toole. ${ }^{25,26}$

Furthermore, recent experiments have demonstrated that cells adhered to surfaces and not associated with biofilms have resistance profiles that are similar to biofilm cells. ${ }^{27,28}$ This resistance phenotype does not require mutations in genomic DNA, as the process is reversible and cells become susceptible to antibiotics after detachment. John et al. suggest that surface attachment facilitates antibiotic resistance by two primary mechanisms: (1) reducing the net negative charge on bacterial cells; and (2) enhancing the stability of the membrane. ${ }^{27}$ Mutations in genes that produce similar phenotypes decrease the susceptibility of bacteria to antibiotics. These data suggest that the attachment of bacteria to surfaces alters their metabolic state and reduces antibiotic susceptibility, which is a common feature of bacteria during the stationary phase of cell growth. ${ }^{29}$ Even surface attachment per se may not be required for this phenotype, as very high densities of cells (similar to the densities obtained in a biofilm) also display antibiotic resistance. ${ }^{30}$ However, attachment to surfaces is one means by which bacterial communities can attain such high densities.

In addition to antibiotic resistance, cells in biofilms often gain protection from predators. When exposed to protozoa, the bacterium Serratia marcescens rapidly forms surfaceassociated microcolonies - an early stage in biofilm formation - that protect cells from grazing by these predators. ${ }^{31}$ Mechanisms of chemical sensing trigger the production of compounds that are toxic to protozoans during $S$. marcescens biofilm development, which provides a further layer of protection from predation. 
Bacteria that are attached to surfaces—particularly those associated with biofilms-may become specialized in comparison to cells in other regions of the community. ${ }^{32}$ In Bacillus subtilis biofilms, motile cells, EPS-producing cells, and spore-forming cells are localized to different regions within the biofilm. Strains of $B$. subtilis that are unable to form structured biofilms do not sporulate, which suggests that localization/specialization is required for the formation of bacterial spores. ${ }^{33}$ Similarly, surface-associated microcolonies and biofilms of Pseudomonas aeruginosa contain groups of cells that display differential motility and susceptibility to antimicrobial agents. ${ }^{34,35}$

Surface sensing is a precursor to swarming, an important adaptive behavior in which contact between cells and surfaces programs morphological changes that facilitate cooperative behavior, rapid community growth, and migration of communities. ${ }^{36,37}$ Swarming motility has been reported in at least 15 different genera of bacteria from different natural habitats. ${ }^{36}$ Several mechanisms of adaptation have been reported during bacterial swarming, including reduced susceptibility to antibiotics ${ }^{38,39}$ and mutualistic interactions with fungal spores..$^{40}$ In B. subtilis swarming colonies, spatially distinct groups of cells express different levels of flagellin — the protein that assembles into the flagellar filament—and have different cell morphologies. ${ }^{41,42}$ Similarly, Proteus mirabilis cells with distinct cell morphologies are found in different regions of swarming communities. ${ }^{43,44}$

Cells in bacterial communities such as swarms or biofilms interact with each other in several different ways. Bacteria are able to communicate through the use of small molecule chemical messengers in a process referred to as 'quorum sensing'. ${ }^{45}$ The dense packing of cells in bacterial communities facilitates an increase in the concentration of small molecules that transfer information between cells and trigger physiological changes. ${ }^{46}$ The shape of chemical gradients in close proximity to surfaces enhances the exchange of chemical information within biofilms and communities attached to surfaces. ${ }^{47-49}$ Lateral gene transfer is also enhanced in biofilms compared to planktonic cells freely suspended in fluids. ${ }^{50}$ Additionally, surface-associated growth induces phenotypes that promote "natural competence" in Vibrio cholerae..$^{51}$ Myxobacteria cells that are associated with biofilms even exchange outer membrane proteins and lipids. ${ }^{52}$

Adhering to surfaces also has several disadvantages, including the inhibition of motility, often due to a "switch" in the activation of genes involved in motility and adhesion: for example, genes coding for flagella may be turned off by the same transcriptional regulator that turns on genes for extracellular matrix production. ${ }^{53-55}$ Inhibiting cell motility prevents cells from searching for optimal environments when nutrients become depleted. Bacterial cells may overcome this disadvantage (and others) in certain environments by sensing surfaces and triggering surface-associated phenotypes that activate motility and prevent adhesion. For example, the process of swarming provides many of the same advantages described earlier, activates cell motility, and provides a mechanism for actively capturing nutrients. ${ }^{38}$ Some pathogens also use surface sensing as a trigger to upregulate virulence factors as a prelude to invasion of the host. ${ }^{56}$

\section{Mechanisms of bacterial attachment}

Many bacteria are freely suspended in bulk fluids before attaching to surfaces. Motile bacteria occupy one of three regions of fluids: (1) bulk liquid, where the cells do not experience effects from the surface; (2) near-surface bulk liquid, where the cells experience the hydrodynamic effects of the surface; and (3) near-surface constrained, where the cells experience both the hydrodynamic and physicochemical (i.e. van der Waals and electrostatic forces) effects of the surface. ${ }^{57}$ The role of physicochemical effects in bacterial adhesion to surfaces has been reviewed in detail by Bos and colleagues. ${ }^{58}$ 
At low and moderate fluid velocities, non-motile bacteria adhere to surfaces. At high fluid velocity, non-motile bacteria are transported with the flow of fluids and do not attach. ${ }^{59}$ Motile bacteria attach to surfaces regardless of fluid velocity. Importantly, the difference between motile and non-motile bacteria occurs only when motile cells actuate their flagella; bacteria with non-functional flagella adhere similarly to cells lacking flagella. ${ }^{59}$ The buoyant density of bacteria (i.e. E. coli) is usually $1.06-1.13 \mathrm{~g} \mathrm{~mL}^{-1,60}$ and leads to the slow deposition of cells onto surfaces from suspension in bulk liquid. Sedimentation rates for different marine bacteria have been measured and range from 10 to $30 \mu \mathrm{m} \mathrm{h}^{-1}{ }^{61}$

Interestingly, the buoyant density of E. coli cells increases as they enter stationary phase, which facilitates their rapid deposition on surfaces. ${ }^{62}$ Populations of cells that make contact with surfaces may thus be enriched with stationary phase cells. In contrast, the buoyant density of Vibrio parahaemolyticus cells decreases as they enter stationary phase. ${ }^{63}$

Upon contacting surfaces, cell attachment occurs in two phases. Initial attachment is reversible, occurs rapidly (on the order of $\sim 1 \mathrm{~min}$ ), ${ }^{64,65}$ and involves hydrodynamic and electrostatic interactions. During this time period, the adhesive force between bacteria and surfaces increases rapidly. A similar phenomenon has been observed for the attachment of polystyrene beads to a surface, ${ }^{66}$ and several observations suggest that this phenomenon is due to physicochemical effects (and not biological effects) including: (1) the loss of interfacial water; (2) structural changes in surface molecules; and (3) repositioning of the cell body to maximize attachment to the surface ${ }^{67}$ Most bacteria have a net negative surface charge - particularly during the early stationary phase of cell growth ${ }^{68}$-and interact preferentially with positively charged surfaces. This effect disappears in high ionic strength media due to charge screening. ${ }^{69}$ Quorum sensing in E. coli causes an increase in the negative charge on cell surfaces, which may facilitate the interaction of bacteria with surfaces during the initial stages of biofilm formation. ${ }^{70}$

The second step of attachment is irreversible, occurs on a time scale of several hours, and involves van der Waals interactions between the hydrophobic region of the outer cell wall and the surface ${ }^{69}$ In addition, several proteins play roles in the transition from reversible to irreversible cell attachment. The cytoplasmic $P$. aeruginosa protein SadB is required for this transition, although its mechanism is unknown. ${ }^{71}$ In E. coli, both lipopolysaccharide (LPS) and pili increase the initial rate of cell attachment and the rate of conversion to irreversible attachment. ${ }^{72}$ In Pseudomonas fluorescens, an $\mathrm{ABC}$ transporter and a secreted protein are required for irreversible attachment. ${ }^{73}$ Irreversible attachment is also facilitated by the production of EPS, which anchors cells to surfaces. ${ }^{74}$

The first clue that some bacteria can interact specifically with certain surfaces came from early observations that different bacteria occupying the same niche do not necessarily interact with the same surfaces. Streptococcus mutans binds to teeth but not the tongue; Streptococcus salivarius displays an opposite preference. ${ }^{75}$ Bacteria have several different classes of extracellular organelles that mediate specific attachment to surfaces, including flagella, pili (also called fimbrae), and curli fibers (Fig. 1a). ${ }^{76}$ These organelles are frequently terminated with proteins referred to as adhesins, which bind to molecules presented on the surface of hosts. Two E. coli examples include type I pili, which bind to glycoproteins that present alpha-D-mannose, and type IV pili, which bind to phosphatidylethanolamine. ${ }^{77}$ Several species of oral bacteria adhere specifically to prolinerich proteins in saliva. ${ }^{78,79}$ One particularly interesting example of specific attachment involves Flavobacterium johnsoniae. SprB is an adhesin that is required for $F$. johnsoniae motility on agar (not on glass). SprB binds to agar surfaces, is moved along the cell surface, and produces cell motion relative to the agar surface. Predicted homologs of SprB in the $F$. johnsoniae genome may facilitate cell attachment and motility on surfaces other than agar. ${ }^{80}$ 
Reversible cell attachment does not necessarily lead to irreversible attachment during surface colonization. In E. coli, weak cell adhesion facilitated by the pilus tip adhesin FimH enables cells to roll along surfaces. FimH mediates binding to glycoproteins that have Nlinked oligosaccharides presenting terminal mannose residues. ${ }^{81}$ FimH binding to monomannose is dependent on shear stress, with a certain threshold level of force required to switch from weak to strong adherence. ${ }^{82}$ Anderson and co-workers observed that a wild type strain of $E$. coli that adhered weakly to mannosylated surfaces colonized the surface more rapidly than a mutant strain only capable of strong (irreversible) attachment. ${ }^{83}$

\section{Cell attachment to different classes of materials}

Bacterial attachment to surfaces is problematic in a wide range of areas, including medical implants,${ }^{84}$ water purification systems, ${ }^{85}$ and industrial processes ${ }^{86}$ The biofouling of metal ship hulls frequently begins with bacterial adhesion before progressing to larger marine organisms, and despite the use of anti-fouling coatings has been estimated to cost $\sim \$ 56 \mathrm{bn} /$ year (US) for a single class of Navy ships. ${ }^{87}$ Thermodynamics plays a central role in regulating the binding of bacteria to surfaces. Cells attach preferentially to hydrophilic materials (i.e., materials with a large surface energy) when the surface energy of the bacterium is larger than the surface energy of the liquid in which they are suspended. The surface energy of bacteria is typically smaller than the surface energy of liquids in which cells are suspended, and this mismatch causes cells to attach preferentially to hydrophobic materials (i.e., materials with lower surface energies). ${ }^{88}$ Bacteria are able to attach to a wide variety of different materials, including glass, aluminum, stainless steel, various organic polymers, ${ }^{72}$ and fluorinated materials such as Teflon ${ }^{\mathrm{TM}} .{ }^{89}$ Table 1 summarizes relevant studies in this area and the diversity of materials used to study bacterial adhesion to surfaces. Banerjee et al. have recently reviewed the materials aspects of bacterial adhesion in detail. ${ }^{90}$

Bacteria also attach to surfaces that initially resist the attachment of cells. This process occurs through the deposition of a layer of proteins-including proteins found naturally in the environment as well as those secreted by bacteria-that "condition" the surface and mask functional groups that reduce cell adhesion. ${ }^{91,92}$ The formation of conditioning layers presents a challenge for creating surfaces that are bacteria-resistant. An excellent case in point is surfaces that present quaternary ammonium salts, which are initially bactericidal before conditioning layers are deposited. ${ }^{93,94}$ Despite the challenges presented by biofouling, the development of surfaces that resist bacterial attachment is an active area of research. Several strategies have been described for reducing the attachment of bacteria, including: (1) controlling surface chemistry, ${ }^{95}$ and (2) controlling structural properties of surfaces (Fig. 1b) ${ }^{96}$ Zwitterionic surfaces such as betaine ${ }^{97-99}$ and silver-impregnated surfaces that slowly release silver ions are among the most effective chemical strategies for inhibiting the attachment of bacteria to surfaces. Another strategy is the use of thermoresponsive hydrogels, such as poly( $N$-isopropylacrylamide). Above a critical temperature, this polymer undergoes a phase transition and presents a hydrophobic surface that facilitates cell attachment and growth. When the temperature is decreased, the polymer swells and presents a hydrophilic surface, and adsorbed cells are released from the surface. ${ }^{100,101}$

Polymer brushes, in which one end of a polymer is attached to a surface and the polymer chain is extended into solution, have been successfully used as anti-adhesive coatings. ${ }^{102}$ Surfaces coated with Pluronic F-127—a tri-block co-polymer of polyethylene oxide and polypropylene oxide-reduce the initial attachment and growth rate of Staphylococcus aureus and Staphylococcus epidermidis and enable the removal of biofilms consisting of these organisms using fluid flow. ${ }^{103}$ The same study found that Pluronic F-127-coated surfaces had no effect on Pseudomonas aeruginosa adhesion and biofilm removal. Polymer 
brushes can also be functionalized with antimicrobial peptides, which enhance the overall antimicrobial activity of the surface. ${ }^{104}$

Physical strategies for reducing attachment have frequently been inspired by natural materials such as shark skin and lotus leaves. ${ }^{96}$ Several examples of structured materials that are designed to reduce bacterial attachment include Sharklet ${ }^{\mathrm{TM}}$ technology, ${ }^{105}$ nanostructured surfaces with a low effective stiffness, ${ }^{106}$ and slippery liquid-infused porous surfaces. ${ }^{107}$ These and other strategies for preventing bacterial attachment have recently been reviewed in depth. ${ }^{84,90,108}$ A shift away from materials that prevent cell attachment to materials that enhance growth may provide insight into the properties of surfaces sensed by bacteria and the biological machinery that is involved in this process.

\section{Mechanisms of sensing surfaces and surface properties sensed by bacteria}

Cells that compare a signal input at a time interval to the total signal at a previous time interval are capable of sensing spatial gradients (e.g., a cell that moves from one position at time $t 1$ to another position at time $t 2$ can evaluate the relative concentrations of a given signal at the two time points). ${ }^{109}$ The canonical example of this process in bacteria is the chemotaxis system, which uses membrane-embedded receptors to detect the concentration of extracellular small molecules and ions and influences the direction of bacterial motility. ${ }^{110}$ Recent evidence demonstrates that bacteria are capable of sensing spatial changes in concentrations in certain conditions. Cells of Staphylococcus aureus sense the binding of surface ligands to receptors on one side of its cell body and respond by localizing receptors to the surface-associated region. ${ }^{111}$ This process involves the response of a cell to a step-function rather than an extracellular gradient per se; however, it indicates that bacteria can distinguish between signals arising from spatially distinct subsets of cell surface receptors.

An example of chemical gradients impacting surface-associated bacteria occurs during biofilm formation. Cells adhering to surfaces may trap ions and small molecules in the thin layer of fluid positioned between the cell body and the surface, which forms a microenvironment that has different properties than the bulk liquid (Fig. 1c). When E. coli adheres to surfaces, the $\mathrm{pH}$ of fluid close to the surface decreases below the $\mathrm{pH}$ of the bulk liquid phase and persists for at least $72 \mathrm{~h} .{ }^{112}$ The Cpx two-component system may play a role in connecting $\mathrm{pH}$ sensing and cell-surface responses. ${ }^{113}$ This system is also involved in regulating the expression and assembly of pili in E. coli. ${ }^{114,115}$ Additionally, the decrease in the $\mathrm{pH}$ of fluids in close proximity to surface-associated cells enhances the proton motive force and directly affects cellular bioenergetics. ${ }^{116}$ Cells adhering to surfaces have been shown to produce 2-5-fold more ATP per cell than non-adherent cells. ${ }^{117}$

Similarly to $\mathrm{pH}$, the osmolality of liquids in close proximity to surfaces also changes rapidly when cells attach to substrates. Gram-negative bacteria sense osmolality using OmpA, ${ }^{118}$ and this process leads to changes in the transcription of other genes. OmpA represses cellulose production through the Cpx pathway and increases biofilm formation in E. coli. ${ }^{118}$ This role for OmpA may be conserved among bacteria (or at least among $\gamma$-proteobacteria), as CpxA-mediated sensing of $\mathrm{pH}$ by OmpA has been identified as a required element for biofilm formation in Sodalis glossinidius, an endosymbiont of the tsetse fly. ${ }^{119} \mathrm{OmpR}$ is a cytoplasmic response regulator that is activated by EnvZ and derepresses the expression of genes that code for pili. ${ }^{115}$ Increases in osmolality stabilize conformations of the cytoplasmic domain of EnvZ and increase the autophosphorylation and activation of OmpR. ${ }^{120}$ 
As some surfaces release soluble compounds that attract bacteria, sensing may begin before bacteria come into direct contact with the surface. Chitin is a homopolymer consisting of Nacetyl-D-glucosamine (GlcNAc) and is the second-most abundant natural polysaccharide on the Earth. The degradation of chitin produces GlcNAc monomers and oligomers, which are chemoattractants of $V$. cholerae. ${ }^{121} V$. cholerae cells that sense and move towards the source of GlcNAc adhere to chitin surfaces using type IV MSHA pili. ${ }^{121}$ Cells sense the presence of GlcNAc oligomers using the protein $\mathrm{ChiS}^{122}$ and respond by upregulating the transcription of numerous genes, including genes that code for chitinolytic enzymes and components of type IV pili. ${ }^{121}$

Bacteria that attach to surfaces become physically constrained by surfaces and the close proximity of adjacent, attached cells. These physical constraints can inhibit the rotation of the flagella on motile bacterial cells, which alters cell physiology. The influence of surfaces, viscous liquids, and anti-flagella antibodies on the rotation of flagella on $V$.

parahaemolyticus, ${ }^{123}$ S. marcescens, ${ }^{124}$ and $P$. mirabilis ${ }^{125}$ is sensed by cells and triggers surface-related morphological changes such as those discussed in detail below. While it is unclear exactly how the signal from the flagella is transduced, it has been hypothesized that the membrane-associated Umo proteins play a role in $P$. mirabilis. ${ }^{126-128}$

Other membrane-based mechanisms also play a role in surface sensing. For example, the induction of the Cpx signaling pathway upon surface adhesion of E. coli requires the outer membrane lipoprotein NlpE. ${ }^{129}$ Cell contact with a hydrophobic surface may damage the outer membrane, trigger NlpE, and activate the Cpx pathway, which responds to envelope stress. As described above, the Cpx pathway also plays a role in biofilm formation. ${ }^{130}$

\section{Changes in phenotypes upon contact of cells with surfaces}

Surface sensing triggers a variety of cellular changes. Many of the changes are morphological and facilitate attachment to surfaces. For example, cells of $S$. aureus preferentially localize fibronectin-binding protein when presented with surfaces that display fibronectin. ${ }^{111}$ During E. coli cell adhesion, a decrease in OmpX in the membrane increases the production of EPS and alters antibiotic susceptibility. ${ }^{131}$ During biofilm formation, quorum sensing alters the charge on $E$. coli cells, ${ }^{70}$ which influences binding to surfaces presenting electrostatically attractive charges. Some organisms, including Helicobacter pylori $^{132}$ and $S$. aureus ${ }^{111}$ produce organelles for adhesion only upon cell contact with host tissues. In response to surfaces, $P$. aeruginosa activates the Wsp system, which consists of a complex of proteins that share homology to the chemotaxis system and dynamically localize in cells. WspA is a chemoreceptor-like protein that senses surfaces and transduces a signal through the other Wsp proteins that ultimately leads to the phosphorylation of WspR. ${ }^{133}$ Phosphorylated WspR catalyzes the synthesis of cyclic-di-GMP (c-di-GMP), ${ }^{134}$ which is implicated in biofilm formation, the suppression of swarming motility in $P$. aeruginosa, ${ }^{135,136}$ and the regulation of several motility- or attachment-related systems in bacteria. ${ }^{137,138}$ In $P$. aeruginosa, c-di-GMP affects the activity of the transcription factor FleQ. FleQ, the master regulator of flagella gene expression, also inhibits the expression of genes required for EPS synthesis (the pel operon). FleQ binds to c-di-GMP, and elevated levels of c-di-GMP in vivo relieve the inhibition of pel gene expression by FleQ. ${ }^{139}$ The surface-induced increase and the subsequent role of c-di-GMP in $P$. aeruginosa is among the best-characterized mechanisms of bacterial surface sensing, and provides an example of the influence of physical interfaces on bacterial biochemistry and physiology.

Pathogenic bacteria frequently decouple their division from growth and form filaments in response to the presence of host surfaces. ${ }^{140}$ The filamentation of uropathogenic E. coli facilitates the escape of cells from the host immune response during urinary tract 
infections. ${ }^{141}$ Agrobacterium tumefaciens also filaments upon contact with plant host tissues. ${ }^{142}$

Filamentation also occurs during the surface sensing-associated process of swarming. During swarming, a wide variety of changes occur in the global transcription of bacterial genes. ${ }^{128,143,144}$ These changes produce significant alterations in cell morphology, including an increase in the surface density of flagella and cell length. ${ }^{44}$ Swarming cells also upregulate several infection-related genes, including protease, urease, hemolysin, and proteins that facilitate host invasion. ${ }^{56,128}$

Interestingly, the physical properties of surfaces may influence cell morphology and community structure. The marine bacterium SW5 adheres to and grows on both hydrophobic and hydrophilic surfaces; however, its growth into communities is influenced by surface properties. Cells adhere uniformly to hydrophobic surfaces, form microcolonies, and grow into tightly packed multi-layer biofilms. Fewer cells attach to hydrophilic surfaces, and changes in cell division lead to the formation chains of cells that are $>100 \mu \mathrm{m}$ long. These chains become loosely entangled to form relatively unstructured and less densely packed biofilms. ${ }^{145}$

\section{Methods of study}

A challenge in the field of microbiology has been the limited range of materials that are available for mechanistic studies of cell/surface interactions. Ironically, most of the surfaces that have been designed for studying bacteria are centered upon inhibiting cell growth and stimulating cell death rather than facilitating cell attachment and stimulating cell growth. A limited number of materials have been developed for studying various types of surface interactions and complement agar and agarose. Eladium ${ }^{\mathrm{TM}}$ is a polysaccharide produced by Rhizobium that has been used to screen yeasts for their biofilm-forming abilities. ${ }^{146}$ Gellan (GELRITETM or Gelzan ${ }^{\mathrm{TM}}$ ) is a heterosaccharide derived from Pseudomonas that has been used to culture a variety of clinically important bacteria. ${ }^{147}$ Polyacrylamide (PA) gels ${ }^{148}$ and polyelectrolyte multilayers (PEMs) ${ }^{149}$ provide controllable surfaces for studies of cellsurface interactions.

In contrast to the limited materials that have been used to explore microbe-surface interactions, a wide variety of materials have been implemented to study mammalian cell attachment to surfaces. These biocompatible materials may be translated into studies of bacterial cell attachment and growth, and include: PA, ${ }^{150}$ alginates, ${ }^{151}$ fibronectin-coated silicone elastomers (useful for making patterned substrates and for controlling the stiffness of surfaces), ${ }^{152}$ poly(vinyl alcohol)/chitosan (a biocompatible copolymer), ${ }^{153}$ and a wide variety of other synthetic and natural polymers. ${ }^{154}$ Composite polymeric materials have expanded the available repertoire of surfaces and substrates. For example, gels consisting of hyaluronic acid (HA) and heparin are better substrates for the adhesion of endothelial progenitor cells than pure HA gels. ${ }^{155} \mathrm{New}$ classes of polymers for studying bacteria interactions with surfaces could facilitate a renaissance in this area.

Adhesion between bacteria and surfaces can be measured by a variety of methods, many of which have been reviewed by Bos et al. ${ }^{58}$ Microbial adhesion to hydrocarbons (MATH) involves vortexing mixtures of bacteria and different hydrocarbons and quantifying bacteria adhesion to the hydrocarbon droplets that form. ${ }^{58}$ The number of bacteria that adhere to different types of surfaces can be assayed using various labeling methods, including radioactivity, fluorescence, and crystal violet staining. ${ }^{156}$ Other methods include atomic force microscopy (AFM), total internal reflection microscopy (TIRM), quartz crystal microbalance (QCM), and the use of liquid flow cells. ${ }^{82,83,157-160}$ Coating AFM tips with confluent layers of bacteria enables the measurement of the attractive or repulsive forces 
between bacteria and various materials. ${ }^{161}$ An interesting extension of this technique involves attaching microbeads to an AFM cantilever and coating them with bacteria, growing the bacteria into a biofilm, and measuring the adhesive and viscoelastic properties of the biofilm at different stages. ${ }^{162}$

\section{New opportunities for chemists, materials scientists, and engineers}

Our understanding of the interaction of bacteria with surfaces is remarkably incomplete. This topic seems ideally suited for collaborations between microbiologists and materials scientists, chemists, and engineers as it is poised to benefit from multidisciplinary approaches that are formulated to penetrate into a range of areas, including: (1) identifying the properties of surfaces that are sensed by bacteria; (2) elucidating the molecular mechanisms bacteria use to sense surfaces and their biochemical responses; and (3) determining how to modulate surface properties to provoke a desired cellular response, including changes in morphology, alterations in bioenergetics, or cell death.

One area in particular that may benefit from contributions from the physical sciences is the impact of the conditioning layer of proteins that frequently precedes bacterial attachment to a surface.$^{90}$ Conditioning layers often have the effect of rendering the underlying chemistry of the surface irrelevant, which translates into antimicrobial surfaces that have short lifetimes over which they are effective. Self-polishing and self-peeling anti-fouling coatings consist of exposed layers that gradually delaminate over time and have been a moderately successful approach for overcoming bacterial attachment in industrial applications. ${ }^{163}$ Laboratory studies of bacteria-surface interactions require the prevention of forming conditioning layers. Materials scientists and engineers are uniquely positioned to tackle this challenge.

One difficulty in the study of cell attachment to surfaces is the measurement of cellular responses, in particular changes in gene expression. These assays typically require removing cells from the surface before analyzing mRNA levels. However, the advent of fluorescent reporters enables the measurement of levels of gene expression in real time in cells attached to surfaces. An elegant demonstration of this technique is the measurement of yellow fluorescent protein expression controlled by promoters of cell-state specific genes such as the gene encoding the flagellin protein. ${ }^{33}$ The availability of libraries of fluorescent fusions to a large number of both promoters ${ }^{164}$ and proteins ${ }^{165}$ in E. coli may enable highthroughput screens to identify genes not previously associated with surface adhesion (e.g., by comparing broth-grown cells and biofilms). Recent advances in surface enhanced Raman scattering (SERS) - specifically the peptide-guided localization of nanoparticle probes to the bacterial membrane-may be applied to studying the chemistry of individual cells in bacterial communities and complement genetic profiling approaches described above. ${ }^{166,167}$

Bacterial surface sensing is a phenomenon that is still not well understood at the level of physical chemistry, biochemistry, genetics, and cell biology. The use of chemically and physically defined substrates and new analytical and biochemical techniques-including those described in this review and those yet to be developed - may have a transformative impact on our understanding of bacteria-surface interactions and guide applications in a range of areas, including agriculture, biomedicine, defense, dentistry, food safety, and industrial processing.

\section{Acknowledgments}

We thank Carrie Harwood, Zemer Gitai, and Alex Persat for their discussion and helpful comments. Work on surface sensing in the Weibel lab is supported by the National Science Foundation (DMR-1121288, MCB-1120832) and the National Institutes of Health (1DP2OD008735-01). 


\section{References}

1. Kumada Y, Benson DR, Hillemann D, Hosted TJ, Rochefort DA, Thompson CJ, Wohlleben W, Tateno Y. Proc. Natl. Acad. Sci. U.S.A. 1993; 90:3009-3013. [PubMed: 8096645]

2. Schidlowski M. Nature. 1988; 333:313-318.

3. Whitman WB, Coleman DC, Wiebe WJ. Proc. Natl. Acad. Sci. U.S.A. 1998; 95:6578-6583. [PubMed: 9618454]

4. Costerton JW, Lewandowski Z, Caldwell DE, Korber DR, Lappin-Scott HM. Annu. Rev. Microbiol. 1995; 49:711-745. [PubMed: 8561477]

5. Meadows P. Nature. 1965; 207:1108-1101.

6. Van Houte J, Green D. Infect. Immun. 1974; 9:624-630. [PubMed: 4822863]

7. Ellen R, Gibbons R. Infect. Immun. 1972; 5:826-830. [PubMed: 4564883]

8. Williams R, Gibbons R. Infect. Immun. 1975; 11:711-718. [PubMed: 1168169]

9. Fletcher M. Can. J. Microbiol. 1977; 23:1-6.

10. Fletcher M. J. Gen. Microbiol. 1976; 94:400-404. [PubMed: 781183]

11. Fletcher M, Loeb G. Appl. Environ. Microbiol. 1979; 37:67-72. [PubMed: 16345338]

12. Orstavik D, Orstavik J. J. Oral Rehabil. 1976; 3:139-144. [PubMed: 1066446]

13. Clark W, Gibbons R. Infect. Immun. 1977; 18:514-523. [PubMed: 924680]

14. Clark W, Bammann L, Gibbons R. Infect. Immun. 1978; 19:846-853. [PubMed: 640732]

15. Corlan AD. Medline trend: Automated yearly statistics of PubMed results for any query. 2012 http://dan.corlan.net/medline-trend.html.

16. Katsikogianni M, Missirlis YF. Eur. Cell. Mater. 2004; 8:37-57. [PubMed: 15593018]

17. ZoBell CE. J. Bacteriol. 1943; 46:39-56. [PubMed: 16560677]

18. Heukelekian H, Heller A. J. Bacteriol. 1940; 40:547-558. [PubMed: 16560368]

19. Poindexter JS. Microbiol. Rev. 1981; 45:123-179. [PubMed: 7012570]

20. Grantham MC, Dove PM. Geochim. Cosmochim. Acta. 1996; 60:2473-2480.

21. Nealson KH, Finkel SE. MRS Bull. 2011; 36:380-384.

22. Nevin KP, Kim B-C, Glaven RH, Johnson JP, Woodard TL, Methé BA, DiDonato RJ, Covalla SF, Franks AE, Liu A, Lovley DR. PLoS ONE. 2009; 4:e5628. [PubMed: 19461962]

23. Donlan RM, Costerton JW. Clin. Microbiol. Rev. 2002; 15:167-193. [PubMed: 11932229]

24. Simões M, Pereira MO, Vieira MJ. Water Res. 2005; 39:5142-5152. [PubMed: 16289205]

25. Mah TF, O'Toole GA. Trends Microbiol. 2001; 9:34-39. [PubMed: 11166241]

26. Mah T. Future Microbiol. 2012; 7:1061-1072. [PubMed: 22953707]

27. John A-K, Schmaler M, Khanna N, Landmann R. Antimicrob. Agents Chemother. 2011; 55:35103516. [PubMed: 21576433]

28. Qu Y, Daley AJ, Istivan TS, Rouch DA, Deighton MA. J. Antimicrob. Chemother. 2010; 65:14051411. [PubMed: 20430788]

29. Eun Y-J, Foss MH, Kiekebusch D, Pauw DA, Westler WM, Thanbichler M, Weibel DB. J. Am. Chem. Soc. 2012; 134:11322-11325. [PubMed: 22741745]

30. Connell JL, Wessel AK, Parsek MR, Ellington AD, Whiteley M, Shear JB. mBio. 2010; 1:e00202e00210. [PubMed: 21060734]

31. Queck S-Y, Weitere M, Moreno AM, Rice SA, Kjelleberg S. Environ. Microbiol. 2006; 8:10171025. [PubMed: 16689722]

32. Branda SS, González-Pastor JE, Ben-Yehuda S, Losick R, Kolter R. Proc. Natl. Acad. Sci. U.S.A. 2001; 98:11621-11626. [PubMed: 11572999]

33. Vlamakis H, Aguilar C, Losick R, Kolter R. Genes Dev. 2008; 22:945-953. [PubMed: 18381896]

34. Haagensen JAJ, Klausen M, Ernst RK, Miller SI, Folkesson A, Tolker-Nielsen T, Molin S. J. Bacteriol. 2007; 189:28-37. [PubMed: 17041046]

35. Purevdorj-Gage B, Costerton WJ, Stoodley P. J. Gen. Microbiol. 2005; 151:1569-1576.

36. Copeland MF, Weibel DB. Soft Matter. 2009; 5:1174-1187.

37. Patrick JE, Kearns DB. Mol. Microbiol. 2012; 83:14-23. [PubMed: 22092493] 
38. Butler MT, Wang Q, Harshey RM. Proc. Nat. Acad. Sci. U.S.A. 2010; 107:3776-3781.

39. Wang L, Zhang C, Gong F, Li H, Xie X, Xia C, Chen J, Song Y, Shen A, Song J. Curr. Microbiol. 2011; 63:377-386. [PubMed: 21833667]

40. Ingham CJ, Kalisman O, Finkelshtein A, Ben-Jacob E. Proc. Nat. Acad. Sci. U.S.A. 2011; 108:19731-19736.

41. Chai L, Vlamakis H, Kolter R. MRS Bull. 2011; 36:374-379.

42. Hamze K, Autret S, Hinc K, Laalami S, Julkowska D, Briandet R, Renault M, Absalon C, Holland IB, Putzer H, Séror SJ. Microbiology. 2011; 157:2456-2469. [PubMed: 21602220]

43. Matsuyama T, Takagi Y, Nakagawa Y, Itoh H, Wakita J, Matsushita M. J. Bacteriol. 2000; 182:385-393. [PubMed: 10629184]

44. Tuson HH, Copeland MF, Carey S, Sacotte R, Weibel DB. J. Bacteriol. 2012; 195:368-377. [PubMed: 23144253]

45. Ng WL, Bassler BL. Annu. Rev. Genet. 2009; 43:197-222. [PubMed: 19686078]

46. Frederix, M.; Downie, JA. Advances in Microbial Physiology. Robert, KP., editor. Vol. vol. Volume 58, ch. 2. Academic Press; 2011. p. 23-80.

47. Flickinger ST, Copeland MF, Downes EM, Braasch AT, Tuson HH, Eun Y-J, Weibel DB. J. Am. Chem. Soc. 2011; 133:5966-5975. [PubMed: 21434644]

48. Dilanji GE, Langebrake JB, De Leenheer P, Hagen SJ. J. Am. Chem. Soc. 2012; 134:5618-5626. [PubMed: 22372494]

49. Shrout JD, Tolker-Nielsen T, Givskov M, Parsek MR. MRS Bull. 2011; 36:367-373. [PubMed: 22053126]

50. Madsen JS, Burmølle M, Hansen LH, Sørensen SJ. FEMS Immunol. Med. Microbiol. 2012

51. Meibom KL, Blokesch M, Dolganov NA, Wu C-Y, Schoolnik GK. Science. 2005; 310:1824-1827. [PubMed: 16357262]

52. Pathak DT, Wei X, Bucuvalas A, Haft DH, Gerloff DL, Wall D. PLoS Genet. 2012; 8:e1002626. [PubMed: 22511878]

53. Krasteva PV, Fong JCN, Shikuma NJ, Beyhan S, Navarro MVAS, Yildiz FH, Sondermann H. Science. 2010; 327:866-868. [PubMed: 20150502]

54. Caiazza NC, Merritt JH, Brothers KM, O'Toole GA. J. Bacteriol. 2007; 189:3603-3612. [PubMed: 17337585]

55. Blair KM, Turner L, Winkelman JT, Berg HC, Kearns DB. Science. 2008; 320:1636-1638. [PubMed: 18566286]

56. Allison C, Coleman N, Jones PL, Hughes C. Infect. Immun. 1992; 60:4740-4746. [PubMed: 1398984]

57. Vigeant MA-S, Ford RM, Wagner M, Tamm LK. Appl. Environ. Microbiol. 2002; 68:2794-2801. [PubMed: 12039734]

58. Bos R, Mei HC, Busscher HJ. FEMS Microbiol. Rev. 1999; 23:179-230. [PubMed: 10234844]

59. McClaine JW, Ford RM. Appl. Environ. Microbiol. 2002; 68:1280-1289. [PubMed: 11872478]

60. Kubitschek HE. Crit. Rev. Microbiol. 1987; 14:73-97. [PubMed: 3549158]

61. Inoue K, Nishimura M, Nayak BB, Kogure K. Appl. Environ. Microbiol. 2007; 73:1049-1053. [PubMed: 17158617]

62. Makinoshima H, Nishimura A, Ishihama A. Mol. Microbiol. 2002; 43:269-279. [PubMed: 11985708]

63. Nishino T, Nayak BB, Kogure K. Appl. Environ. Microbiol. 2003; 69:3569-3572. [PubMed: 12788764]

64. Boks NP, Busscher HJ, van der Mei HC, Norde W. Langmuir. 2008; 24:12990-12994. [PubMed: 18942800]

65. Boks NP, Kaper HJ, Norde W, Busscher HJ, van der Mei HC. Colloids Surf. B. Biointerfaces. 2008; 67:276-278. [PubMed: 18835700]

66. Meinders JM, Van der Mei HC, Busscher HJ. J. Colloid Interface Sci. 1995; 176:329-341.

67. Busscher HJ, Norde W, Sharma PK, van der Mei HC. Curr. Opin. Colloid In. 2010; 15:510-517. 
68. Hayashi H, Seiki H, Tsuneda S, Hirata A, Sasaki H. J. Colloid Interface Sci. 2003; 264:565-568. [PubMed: 16256681]

69. Renner LD, Weibel DB. MRS Bull. 2011; 36:347-355. [PubMed: 22125358]

70. Eboigbodin KE, Newton JRA, Routh AF, Biggs CA. Appl. Microbiol. Biotechnol. 2006; 73:669675. [PubMed: 16855837]

71. Caiazza NC, O'Toole GA. J. Bacteriol. 2004; 186:4476-4485. [PubMed: 15231779]

72. Chao Y, Zhang T. Langmuir. 2011; 27:11545-11553. [PubMed: 21842859]

73. Hinsa SM, Espinosa-Urgel M, Ramos JL, O'Toole GA. Mol. Microbiol. 2003; 49:905-918. [PubMed: 12890017]

74. Marshall KC, Stout R, Mitchell R. J. Gen. Microbiol. 1971; 68:337.

75. Beachey EH. J. Infect. Dis. 1981; 143:325-345. [PubMed: 7014727]

76. Van Houdt R, Michiels CW. Res. Microbiol. 2005; 156:626-633. [PubMed: 15950122]

77. Spears KJ, Roe AJ, Gally DL. FEMS Microbiol. Lett. 2006; 255:187-202. [PubMed: 16448495]

78. Newman F, Beeley JA, MacFarlane TW. Electrophoresis. 1996; 17:266-270. [PubMed: 8907552]

79. Amano A, Shizukuishi S, Horie H, Kimura S, Morisaki I, Hamada S. Infect. Immun. 1998; 66:2072-2077. [PubMed: 9573091]

80. Nelson SS, Bollampalli S, McBride MJ. J. Bacteriol. 2008; 190:2851-2857. [PubMed: 18281397]

81. Bouckaert J, Mackenzie J, de Paz JL, Chipwaza B, Choudhury D, Zavialov A, Mannerstedt K, Anderson J, Pierard D, Wyns L, Seeberger PH, Oscarson S, De Greve H, Knight SD. Mol. Microbiol. 2006; 61:1556-1568. [PubMed: 16930149]

82. Nilsson LM, Thomas WE, Trintchina E, Vogel V, Sokurenko EV. J. Biol. Chem. 2006; 281:16656-16663. [PubMed: 16624825]

83. Anderson BN, Ding AM, Nilsson LM, Kusuma K, Tchesnokova V, Vogel V, Sokurenko EV, Thomas WE. J. Bacteriol. 2007; 189:1794-1802. [PubMed: 17189376]

84. Bruellhoff K, Fiedler J, Möller M, Groll J, Brenner RE. Int. J. Artif. Organs. 2010; 33:646-653. [PubMed: 20890881]

85. Kang, G-d; Cao, Y-m. Water Res. 2012; 46:584-600. [PubMed: 22154112]

86. Marcato-Romain CE, Pechaud Y, Paul E, Girbal-Neuhauser E, Dossat-Létisse V. Biofouling. 2012; 28:305-314. [PubMed: 22452390]

87. Schultz MP, Bendick JA, Holm ER, Hertel WM. Biofouling. 2010; 27:87-98. [PubMed: 21161774]

88. Absolom DR, Lamberti FV, Policova Z, Zingg W, van Oss CJ, Neumann AW. Appl. Environ. Microbiol. 1983; 46:90-97. [PubMed: 6412629]

89. Goulter-Thorsen RM, Taran E, Gentle IR, Gobius KS, Dykes GA. Appl. Environ. Microbiol. 2011; 77:7339-7344. [PubMed: 21856839]

90. Banerjee I, Pangule RC, Kane RS. Adv. Mater. 2011; 23:690-718. [PubMed: 20886559]

91. Lejeune P. Trends Microbiol. 2003; 11:179-184. [PubMed: 12706996]

92. Wong SY, Han L, Timachova K, Veselinovic J, Hyder MN, Ortiz C, Klibanov AM, Hammond PT. Biomacromolecules. 2012; 13:719-726. [PubMed: 22300304]

93. Melo LD, Palombo RR, Petri DFS, Bruns M, Pereira EMA, Carmona-Ribeiro AM. ACS Appl. Mater. Interfaces. 2011; 3:1933-1939. [PubMed: 21591705]

94. Tiller JC, Liao C-J, Lewis K, Klibanov AM. Proc. Natl. Acad. Sci. U.S.A. 2001; 98:5981-5985. [PubMed: 11353851]

95. Hook AL, Chang C-Y, Yang J, Luckett J, Cockayne A, Atkinson S, Mei Y, Bayston R, Irvine DJ, Langer R, Anderson DG, Williams P, Davies MC, Alexander MR. Nat. Biotechnol. 2012

96. Bazaka K, Crawford RJ, Ivanova EP. Biotechnol. J. 2011; 6:1103-1114. [PubMed: 21910258]

97. Cheng G, Zhang Z, Chen S, Bryers JD, Jiang S. Biomaterials. 2007; 28:4192-4199. [PubMed: 17604099]

98. Zhang Z, Chao T, Chen S, Jiang S. Langmuir. 2006; 22:10072-10077. [PubMed: 17107002]

99. Zhang Z, Chen S, Chang Y, Jiang S. J. Phys. Chem. B. 2006; 110:10799-10804. [PubMed: 16771329]

100. Ista LK, Mendez S, Pérez-Luna VH, López GP. Langmuir. 2001; 17:2552-2555. 
101. Okano T, Kikuchi A, Sakurai Y, Takei Y, Ogata N. J. Control. Release. 1995; 36:125-133.

102. Senaratne W, Andruzzi L, Ober CK. Biomacromolecules. 2005; 6:2427-2448. [PubMed: 16153077]

103. Nejadnik MR, van der Mei HC, Norde W, Busscher HJ. Biomaterials. 2008; 29:4117-4121. [PubMed: 18674814]

104. Gao G, Yu K, Kindrachuk J, Brooks DE, Hancock REW, Kizhakkedathu JN. Biomacromolecules. 2011; 12:3715-3727. [PubMed: 21902171]

105. Chung KK, Schumacher JF, Sampson EM, Burne RA, Antonelli PJ, Brennan AB. Biointerphases. 2007; 2:89-94. [PubMed: 20408641]

106. Epstein AK, Hochbaum AI, Kim P, Aizenberg J. Nanotechnology. 2011; 22:494007. [PubMed: 22101439]

107. Epstein AK, Wong T-S, Belisle RA, Boggs EM, Aizenberg J. Proc. Nat. Acad. Sci. U.S.A. 2012; 109:13182-13187.

108. Khoo X, Grinstaff MW. MRS Bull. 2011; 36:357-366.

109. Segall JE, Block SM, Berg HC. Proc. Natl. Acad. Sci. U.S.A. 1986; 83:8987-8991. [PubMed: 3024160]

110. Sourjik V, Armitage JP. EMBO J. 2010; 29:2724-2733. [PubMed: 20717142]

111. Lower SK, Yongsunthon R, Casillas-Ituarte NN, Taylor ES, DiBartola AC, Lower BH, Beveridge TJ, Buck AW, Fowler VG. Biophys. J. 2010; 99:2803-2811. [PubMed: 21044577]

112. Ponsonnet L, Boureanu M, Jaffrezic N, Othmane A, Dorel C, Lejeune P. Mater. Sci. Eng. C. 2008; 28:896-900.

113. Nakayama S, Watanabe H. J. Bacteriol. 1995; 177:5062-5069. [PubMed: 7665485]

114. Hung DL, Raivio TL, Jones CH, Silhavy TJ, Hultgren SJ. EMBO J. 2001; 20:1508-1518. [PubMed: 11285215]

115. Schwan WR, Lee JL, Lenard FA, Matthews BT, Beck MT. Infect. Immun. 2002; 70:1391-1402. [PubMed: 11854225]

116. Brown DG, Hong Y. J. Adhes. Sci. Technol. 2011; 25:2199-2218.

117. Hong Y, Brown DG. Appl. Environ. Microbiol. 2009; 75:2346-2353. [PubMed: 19218409]

118. Ma Q, Wood TK. Environ. Microbiol. 2009; 11:2735-2746. [PubMed: 19601955]

119. Maltz MA, Weiss BL, O'Neill M, Wu Y, Aksoy S. Appl. Environ. Microbiol. 2012

120. Wang LC, Morgan LK, Godakumbura P, Kenney LJ, Anand GS. EMBO J. 2012; 31:2648-2659. [PubMed: 22543870]

121. Meibom KL, Li XB, Nielsen AT, Wu C-Y, Roseman S, Schoolnik GK. Proc. Natl. Acad. Sci. U.S.A. 2004; 101:2524-2529. [PubMed: 14983042]

122. Li X, Roseman S. Proc. Natl. Acad. Sci. U.S.A. 2004; 101:627-631. [PubMed: 14699052]

123. McCarter L, Hilmen M, Silverman M. Cell. 1988; 54:345-351. [PubMed: 3396074]

124. Alberti L, Harshey RM. J. Bacteriol. 1990; 172:4322-4328. [PubMed: 2198253]

125. Belas R, Suvanasuthi R. J. Bacteriol. 2005; 187:6789-6803. [PubMed: 16166542]

126. Cusick K, Lee Y-Y, Youchak B, Belas R. J. Bacteriol. 2012; 194:437-447. [PubMed: 22081397]

127. Dufour A, Furness RB, Hughes C. Mol. Microbiol. 1998; 29:741-751. [PubMed: 9723914]

128. Pearson MM, Rasko DA, Smith SN, Mobley HLT. Infect. Immun. 2010; 78:2834-2845. [PubMed: 20368347]

129. Otto K, Silhavy TJ. Proc. Nat. Acad. Sci. U.S.A. 2002; 99:2287-2292.

130. Dorel C, Lejeune P, Rodrigue A. Res. Microbiol. 2006; 157:306-314. [PubMed: 16487683]

131. Otto K, Hermansson M. J. Bacteriol. 2004; 186:226-234. [PubMed: 14679242]

132. Couturier MR, Stein M. Can. J. Microbiol. 2008; 54:537-548. [PubMed: 18641700]

133. O'Connor JR, Kuwada NJ, Huangyutitham V, Wiggins PA, Harwood CS. Mol. Microbiol. 2012

134. Güvener ZT, Harwood CS. Mol. Microbiol. 2007; 66:1459-1473. [PubMed: 18028314]

135. Hickman JW, Tifrea DF, Harwood CS. Proc. Natl. Acad. Sci. U.S.A. 2005; 102:14422-14427.

[PubMed: 16186483] 
136. Kuchma SL, Brothers KM, Merritt JH, Liberati NT, Ausubel FM, O'Toole GA. J. Bacteriol. 2007; 189:8165-8178. [PubMed: 17586641]

137. Hengge R. Nat. Rev. Microbiol. 2009; 7:263-273. [PubMed: 19287449]

138. Simm R, Morr M, Kader A, Nimtz M, Römling U. Mol. Microbiol. 2004; 53:1123-1134. [PubMed: 15306016]

139. Hickman JW, Harwood CS. Mol. Microbiol. 2008; 69:376-389. [PubMed: 18485075]

140. Justice SS, Hunstad DA, Cegelski L, Hultgren SJ. Nat. Rev. Microbiol. 2008; 6:162-168. [PubMed: 18157153]

141. Horvath DJ, Li B, Casper T, Partida-Sanchez S, Hunstad DA, Hultgren SJ, Justice SS. Microb. Infect. 2011; 13:426-437.

142. Finer KR, Larkin KM, Martin BJ, Finer JJ. Plant Cell Rep. 2001; 20:250-255.

143. Salvetti S, Faegri K, Ghelardi E, Kolstø A-B, Senesi S. Appl. Environ. Microbiol. 2011; 77:5149_ 5156. [PubMed: 21642396]

144. Wang Q, Frye JG, McClelland M, Harshey RM. Mol. Microbiol. 2004; 52:169-187. [PubMed: 15049819]

145. Dalton HM, Poulsen LK, Halasz P, Angles ML, Goodman AE, Marshall KC. J. Bacteriol. 1994; 176:6900-6906. [PubMed: 7961450]

146. Gognies S, Belarbi A. Appl. Microbiol. Biotechnol. 2010; 88:1095-1102. [PubMed: 20703874]

147. Shungu D, Valiant M, Tutlane V, Weinberg E, Weissberger B, Koupal L, Gadebusch H, Stapley E. Appl. Environ. Microbiol. 1983; 46:840-845. [PubMed: 16346398]

148. Tuson HH, Renner LD, Weibel DB. Chem. Comm. 2012; 48:1595-1597. [PubMed: 22039586]

149. Lichter JA, Thompson MT, Delgadillo M, Nishikawa T, Rubner MF, Van Vliet KJ. Biomacromolecules. 2008; 9:1571-1578. [PubMed: 18452330]

150. Pelham RJ Jr, Wang Y-L. Proc. Nat. Acad. Sci. U.S.A. 1997; 94:13661-13665.

151. Boontheekul T, Hill EE, Kong H-J, Mooney DJ. Tissue Eng. 2007; 13:1431-1442. [PubMed: 17561804]

152. McBeath R, Pirone DM, Nelson CM, Bhadriraju K, Chen CS. Dev. Cell. 2004; 6:483-495. [PubMed: 15068789]

153. Minoura N, Koyano T, Koshizaki N, Umehara H, Nagura M, Kobayashi K-i. Mater. Sci. Eng. C. 1998; 6:275-280.

154. Drury JL, Mooney DJ. Biomaterials. 2003; 24:4337-4351. [PubMed: 12922147]

155. Camci-Unal G, Nichol JW, Bae H, Tekin H, Bischoff J, Khademhosseini A. J. Tissue Eng. Regen. Med. 2012

156. Vesterlund S, Paltta J, Karp M, Ouwehand AC. J. Microbiol. Methods. 2005; 60:225-233. [PubMed: 15590097]

157. Camesano TA, Liu Y, Datta M. Adv. Water Resour. 2007; 30:1470-1491.

158. Otto K. Res. Microbiol. 2008; 159:415-422. [PubMed: 18550342]

159. Mosier AP, Cady NC. Sci. Prog. 2011; 94:431-450. [PubMed: 22308903]

160. Shen Y, Siryaporn A, Lecuyer S, Gitai Z, Stone HA. Biophys. J. 2012; 103:146-151. [PubMed: 22828341]

161. Razatos A, Ong Y-L, Sharma MM, Georgiou G. Proc. Nat. Acad. Sci. U.S.A. 1998; 95:1105911064.

162. Lau PCY, Dutcher JR, Beveridge TJ, Lam JS. Biophys. J. 2009; 96:2935-2948. [PubMed: 19348775]

163. Xie L, Hong F, He C, Ma C, Liu J, Zhang G, Wu C. Polymer. 2011

164. Zaslaver A, Bren A, Ronen M, Itzkovitz S, Kikoin I, Shavit S, Liebermeister W, Surette MG, Alon U. Nat. Methods. 2006; 3:623-628. [PubMed: 16862137]

165. Taniguchi Y, Choi PJ, Li G-W, Chen H, Babu M, Hearn J, Emili A, Xie XS. Science. 2010; 329:533-538. [PubMed: 20671182]

166. Athamneh AIM, Senger RS. Appl. Environ. Microbiol. 2012

167. Efrima S, Zeiri L. J. Raman Spectrosc. 2009; 40:277-288. 
168. Cheung H-Y, Chan GK-L, Cheung S-H, Sun S-Q, Fong W-F. J. Appl. Microbiol. 2007; 102:701710. [PubMed: 17309619]

169. Dexter SC, Sullivan JD, Williams J, Watson SW. Appl. Microbiol. 1975; 30:298-308. [PubMed: 16350027]

170. Wei J, Ravn DB, Gram L, Kingshott P. Colloids Surf. B. Biointerfaces. 2003; 32:275-291.

171. Cao Z, Mi L, Mendiola J, Ella-Menye J-R, Zhang L, Xue H, Jiang S. Angew. Chem. 2012; 51:2602-2605. [PubMed: 22213162]

172. Schaer TP, Stewart S, Hsu BB, Klibanov AM. Biomaterials. 2012; 33:1245-1254. [PubMed: 22082621]

173. Behlau I, Mukherjee K, Todani A, Tisdale AS, Cade F, Wang L, Leonard EM, Zakka FR, Gilmore MS, Jakobiec FA, Dohlman CH, Klibanov AM. Biomaterials. 2011; 32:8783-8796. [PubMed: 21903257]

174. Cheng G, Li G, Xue H, Chen S, Bryers JD, Jiang S. Biomaterials. 2009; 30:5234-5240. [PubMed: 19573908]

175. Oliveira R, Melo L, Oliveira A, Salgueiro R. Colloids Surf. B. Biointerfaces. 1994; 2:41-46.

176. Roosjen A, van der Mei HC, Busscher HJ, Norde W. Langmuir. 2004; 20:10949-10955. [PubMed: 15568845]

177. Roosjen A, de Vries J, van der Mei HC, Norde W, Busscher HJ. J. Biomed. Mater. Res., Part B. 2005; 73:347-354.

178. Pidhatika B, Möller J, Benetti EM, Konradi R, Rakhmatullina E, Mühlebach A, Zimmermann R, Werner C, Vogel V, Textor M. Biomaterials. 2010; 31:9462-9472. [PubMed: 21059465]

179. Chang Y, Yandi W, Chen W-Y, Shih Y-J, Yang C-C, Chang Y, Ling Q-D, Higuchi A. Biomacromolecules. 2010; 11:1101-1110. [PubMed: 20201492]

180. Cunliffe D, Smart CA, Tsibouklis J, Young S, Alexander C, Vulfson EN. Biotechnol. Lett. 2000; 22:141-145.

181. Cheng G, Xue H, Li G, Jiang S. Langmuir. 2010; 26:10425-10428. [PubMed: 20518560]

182. Ong Y-L, Razatos A, Georgiou G, Sharma MM. Langmuir. 1999; 15:2719-2725.

183. Patel JD, Ebert M, Ward R, Anderson JM. J. Biomed. Mater. Res. A. 2007; 80:742-751. [PubMed: 17177270]

184. Ostuni E, Chapman RG, Liang MN, Meluleni G, Pier G, Ingber DE, Whitesides GM. Langmuir. 2001; 17:6336-6343.

185. Tegoulia VA, Cooper SL. Colloids Surf. B. Biointerfaces. 2002; 24:217-228.

186. Vassilakos N, Kalfas S, Arnebrant T, Rundegren J. Colloids Surf. B. Biointerfaces. 1993; 1:341347.

187. Chen S, Chen S, Jiang S, Mo Y, Luo J, Tang J, Ge Z. Colloids Surf. B. Biointerfaces. 2011; 85:323-329. [PubMed: 21450443] 


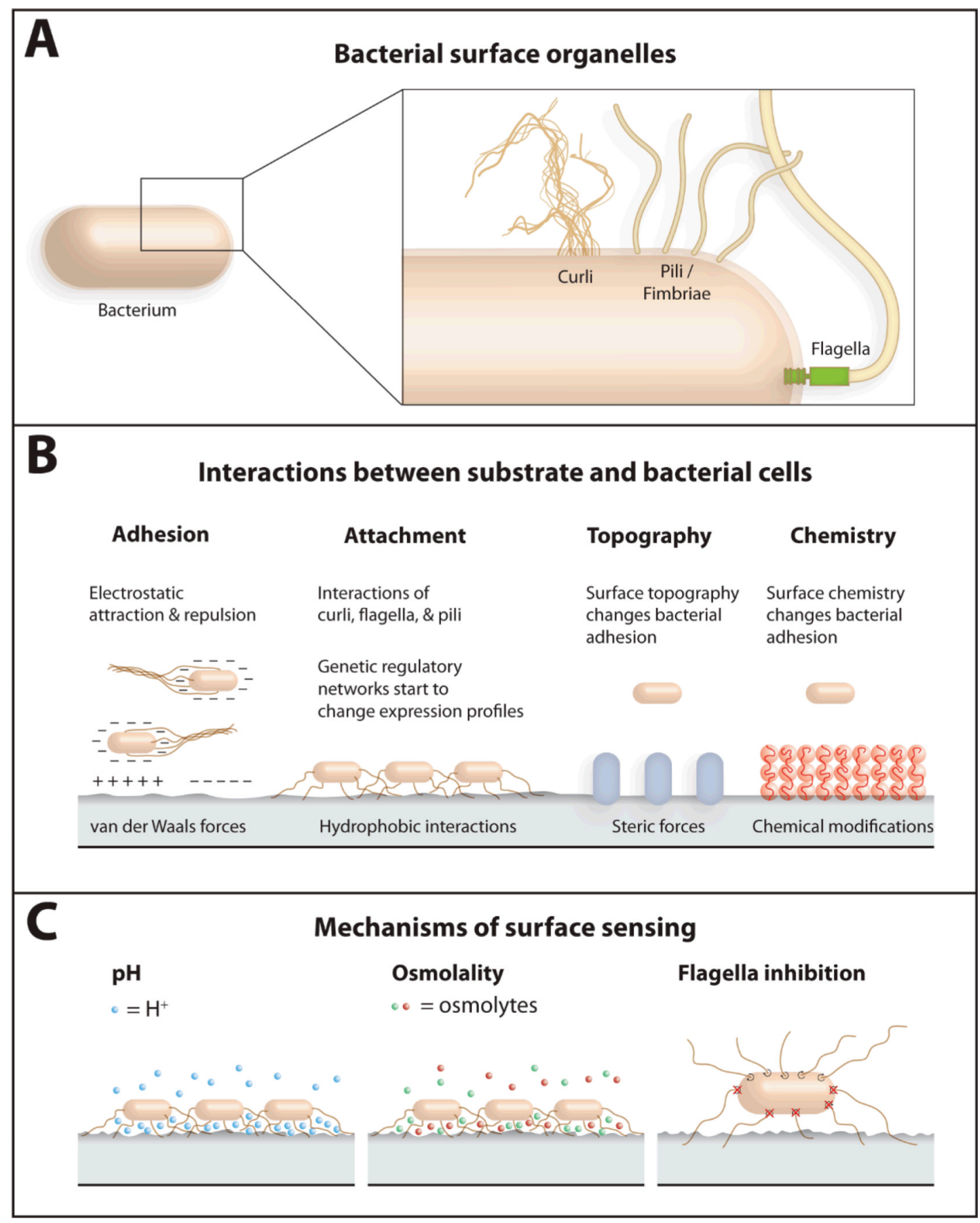

Figure 1.

Several aspects of bacterial interaction with substrates are highlighted. (A) The bacterial surface has several organelles that facilitate interactions with substrates, including curli fibers, pili (also called fimbrae), and flagella. (B) Properties of the surface such as charge, hydrophobicity, topography, and the identity of the exposed chemical groups interact with physico-chemical properties of bacterial cells and influence attachment. (C) The proximity of bacteria to a surface causes changes in $\mathrm{pH}$, osmolality, and flagella rotation that are sensed by cells. Figure adapted from Ref. 69. 


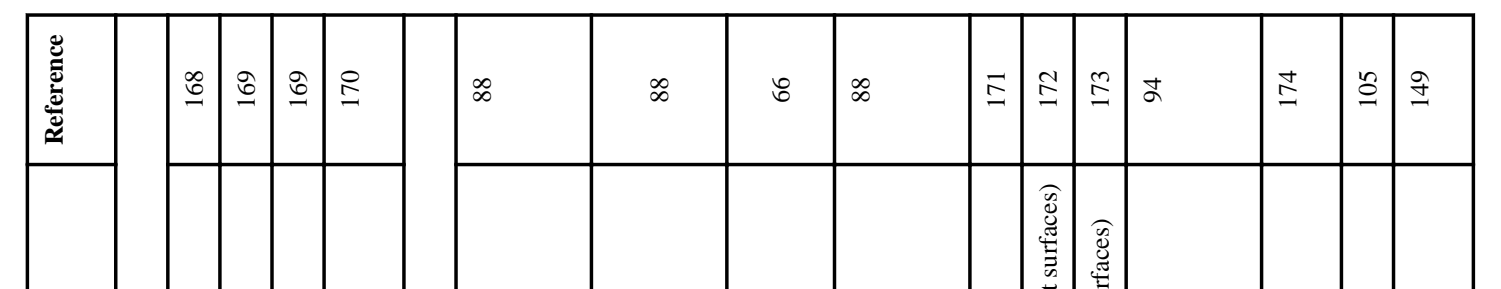

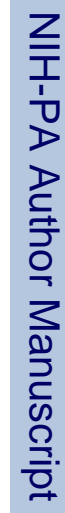

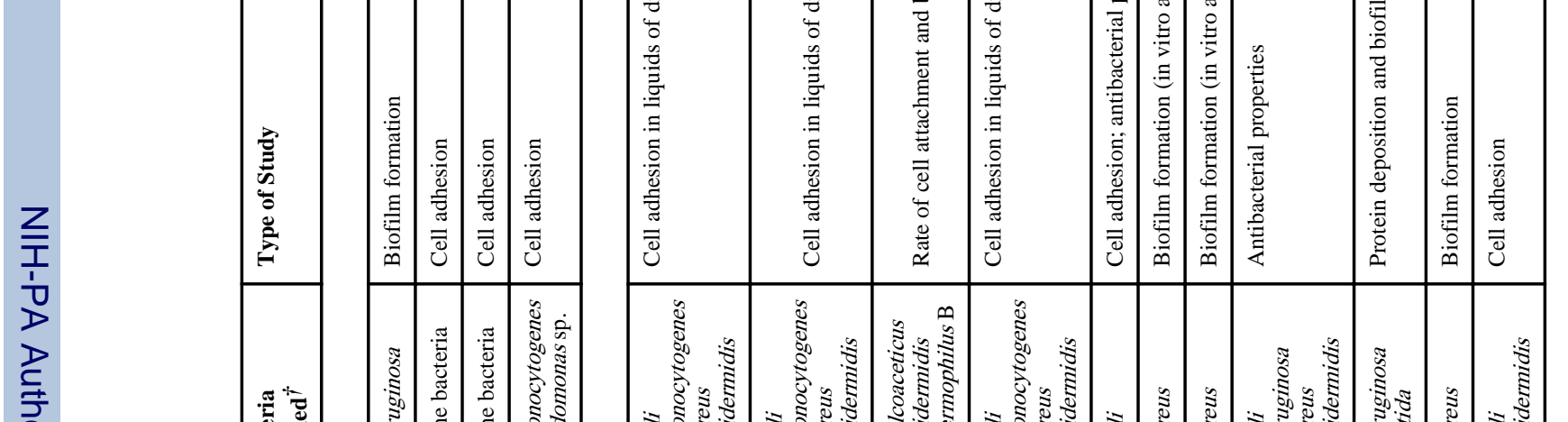

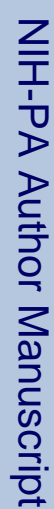

䇺
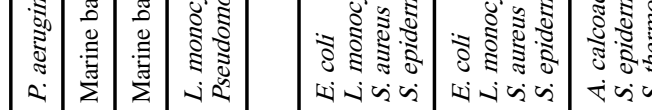

8ำ 을

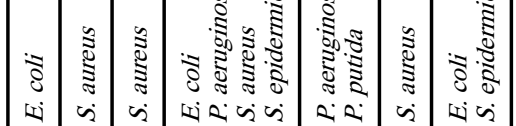
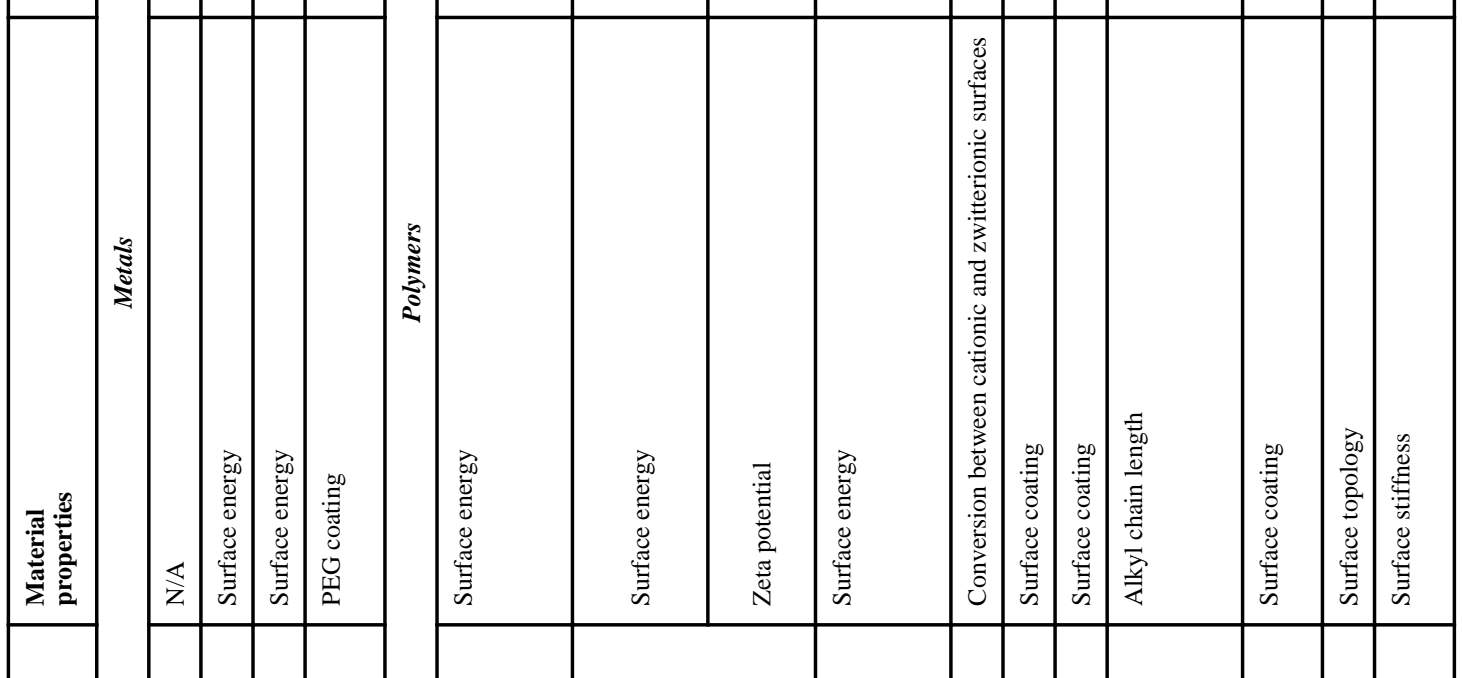

-

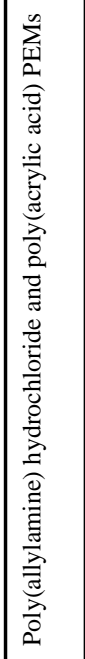




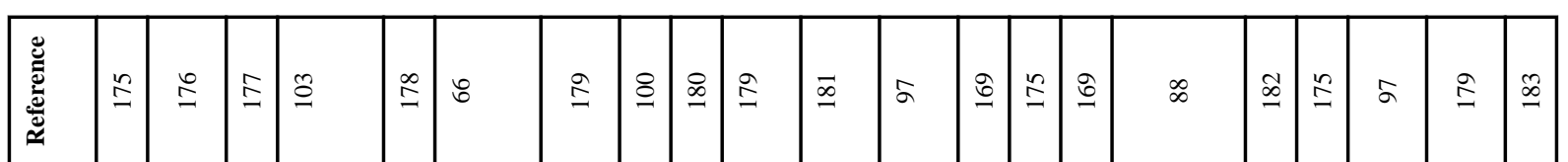

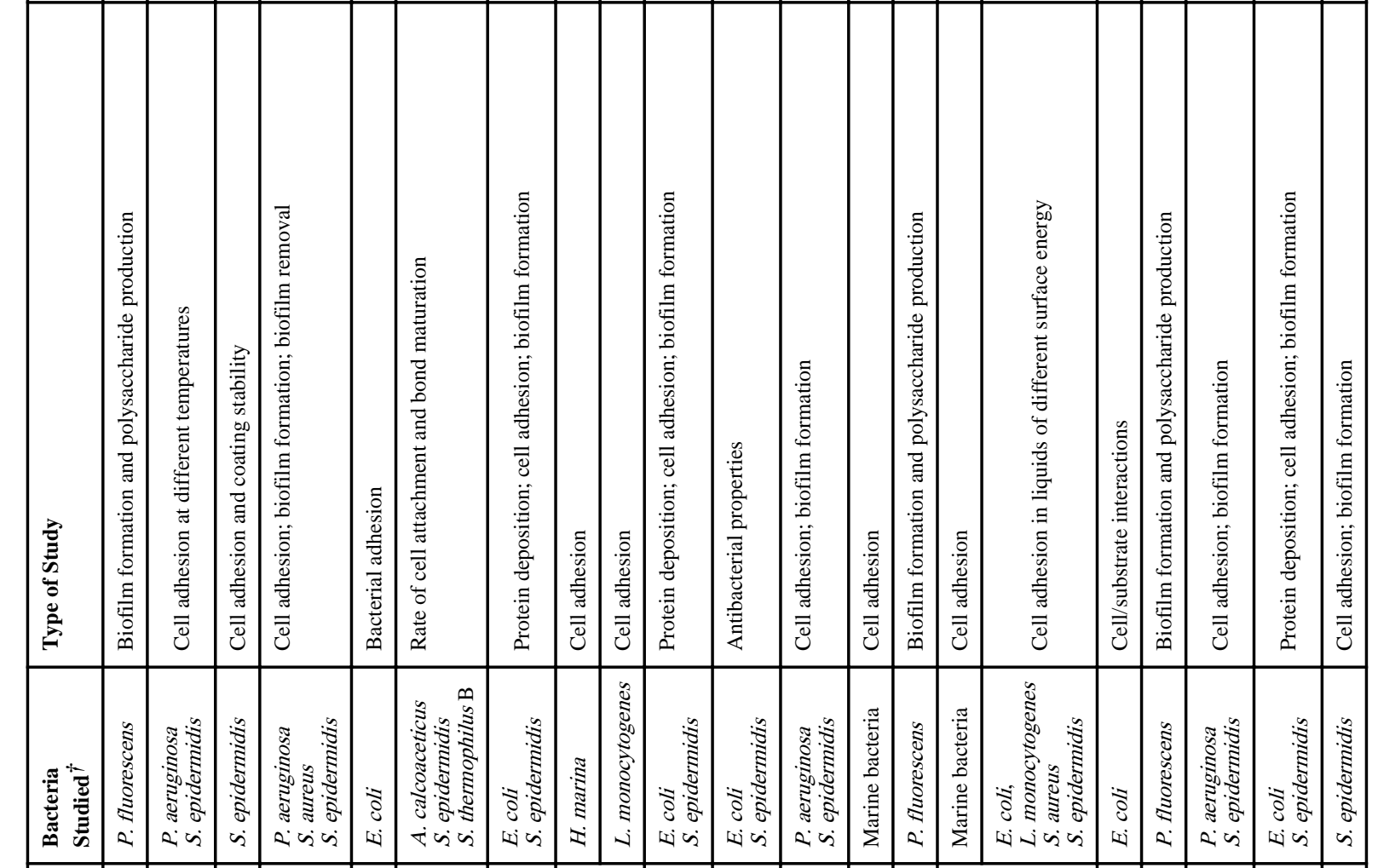

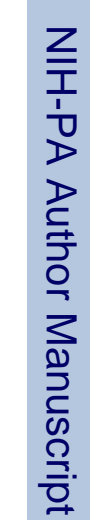
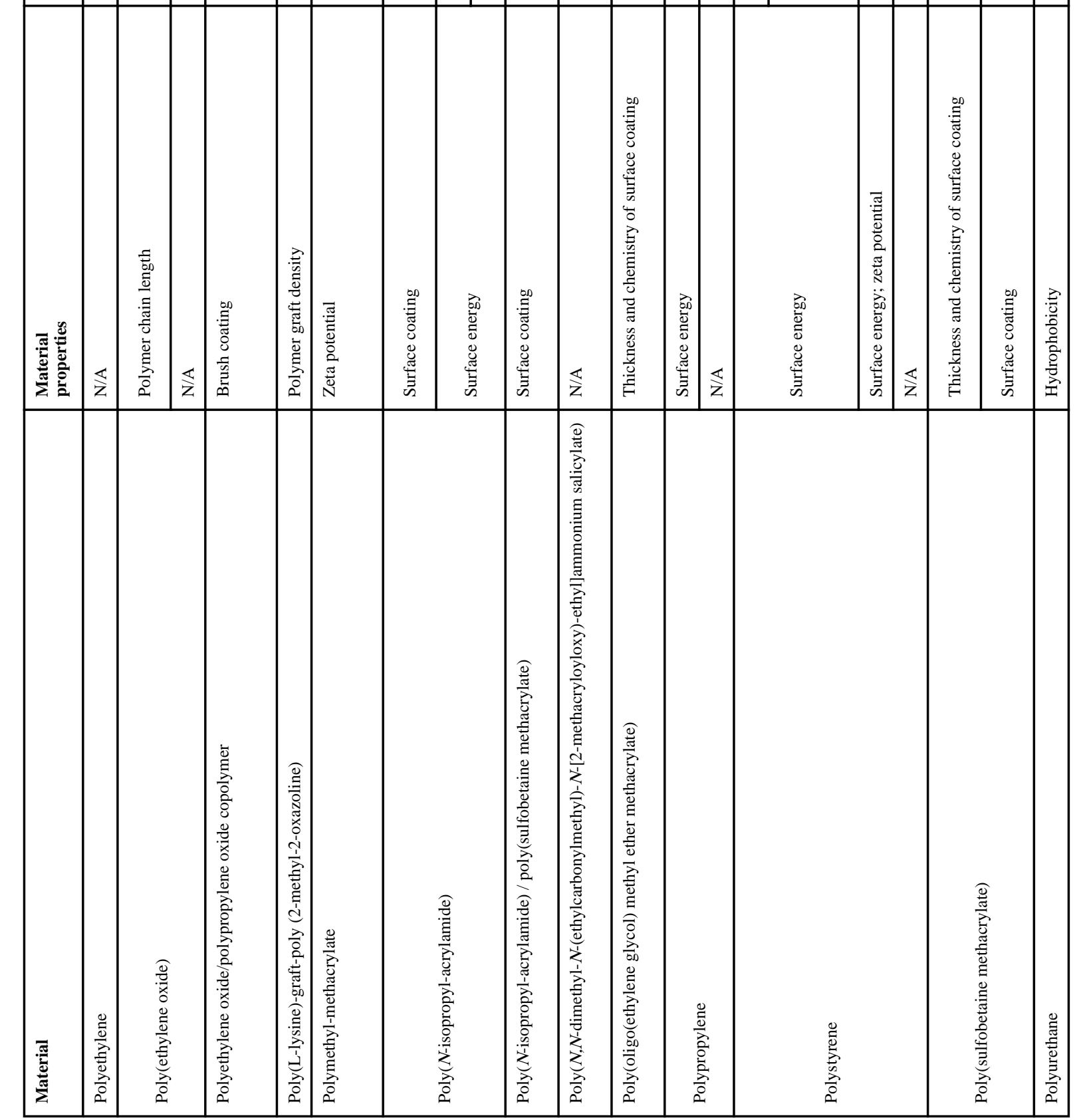


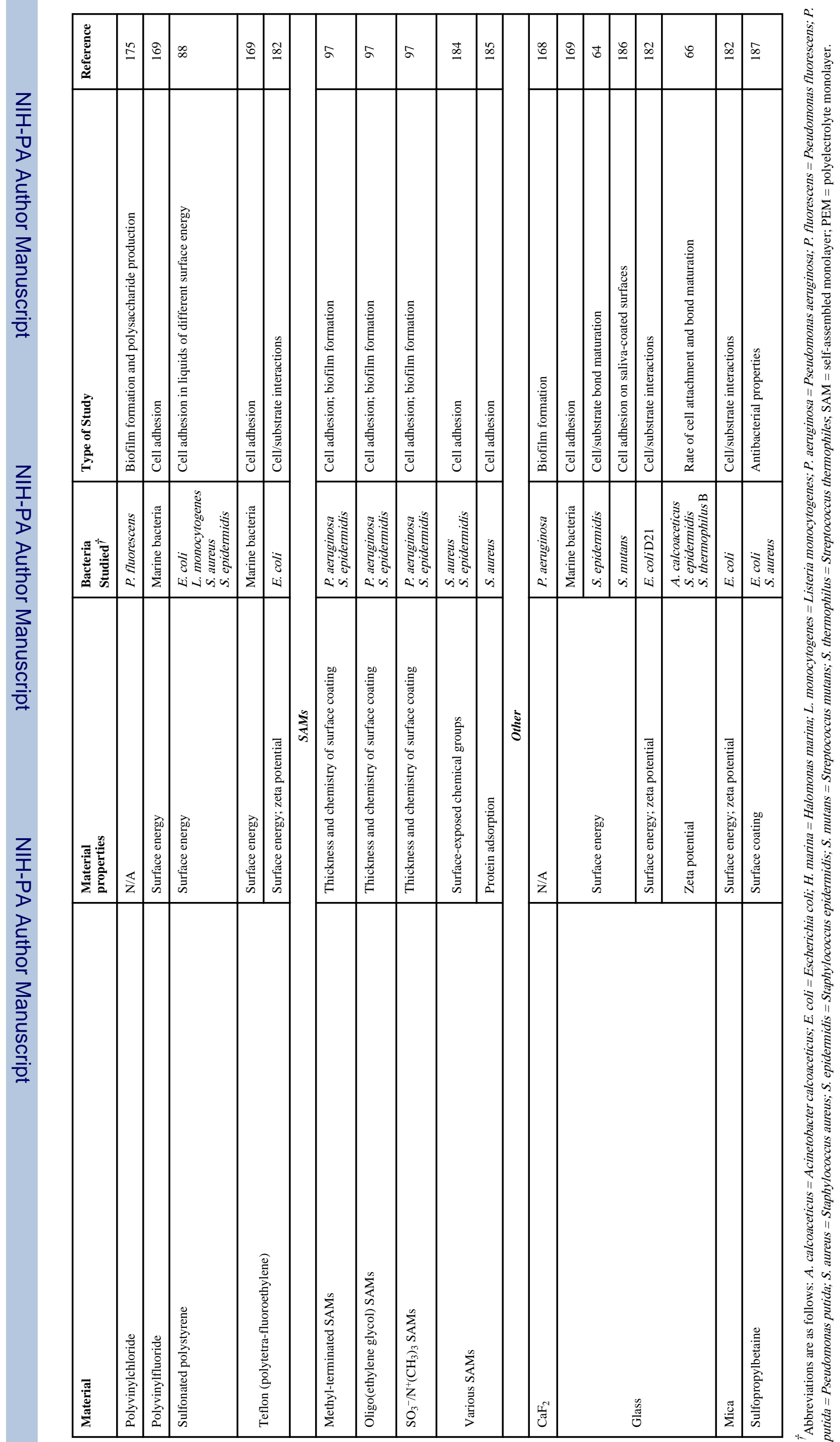

